\title{
Cleaning-up Bank Balance \\ Sheets: Economic, Legal, and Supervisory Measures for Italy
}




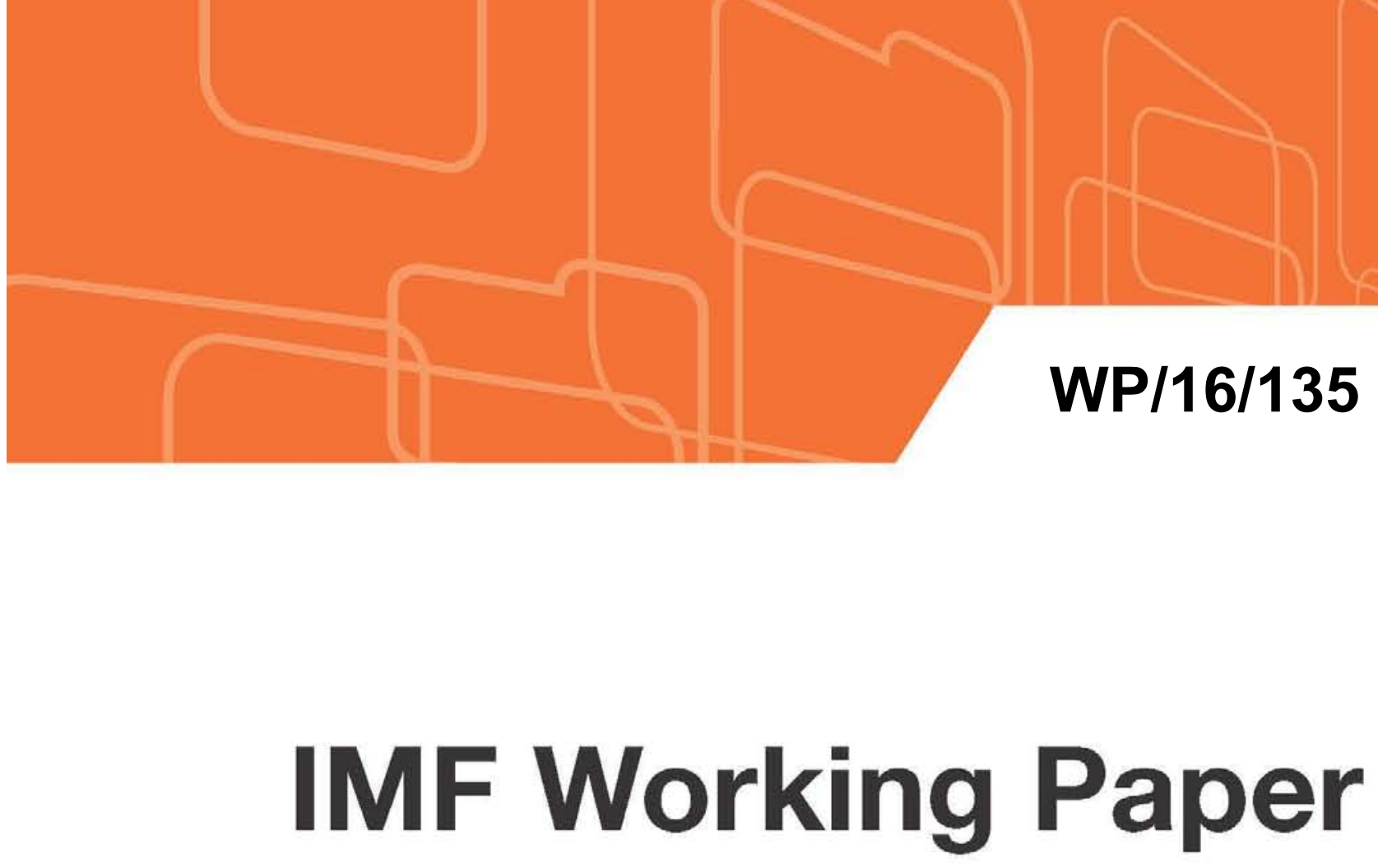

Cleaning-up Bank Balance Sheets: Economic, Legal, and Supervisory Measures for Italy

by José Garrido, Emanuel Kopp, and Anke Weber

I N T ER N A T I O N A L MONETAR Y FU N D 


\title{
IMF Working Paper
}

\author{
European Department
}

\section{Cleaning-up Bank Balance Sheets: Economic, Legal, and Supervisory Measures for Italy}

\section{Prepared by José Garrido, Emanuel Kopp, and Anke Weber ${ }^{1}$}

Authorized for distribution by Rishi Goyal

July 2016

IMF Working Papers describe research in progress by the author(s) and are published to elicit comments and to encourage debate. The views expressed in IMF Working Papers are those of the author(s) and do not necessarily represent the views of the IMF, its Executive Board, or IMF management.

\begin{abstract}
To stabilize and bring down nonperforming loans (NPLs) in the Italian banking system, the Italian authorities have been implementing a number of reforms, aimed among others at speeding up insolvency and enforcement proceedings, strengthening bank corporate governance, cleaning up balance sheets, and facilitating bank consolidation. This paper examines the Italian banking system's NPL problem, which ties up capital, weighing on bank profitability and authorities' economic reforms. It argues for a comprehensive approach, encompassing economic, supervisory, and legal measures. The authorities' reforms are important steps toward this end. The paper describes measures that could further support their actions.
\end{abstract}

JEL Classification Numbers: E440, K22, G33, G38

Keywords: Nonperforming loans, corporate restructuring, asset management companies.

Author's E-Mail Address: jgarrido@,imf.org; ekopp@,imf.org; aweber@,imf.org.

\footnotetext{
${ }^{1}$ The authors would like to thank Paolo Angelini, Athanasios Arvanitis, Wolfgang Bergthaler, Petya Koeva Brooks, Alessio de Vincenzo, Marc Dobler, Paolo Finaldirusso, Giorgio Gobbi, Rishi Goyal, Andreas Jobst, Kenneth Kang, Yan Liu, Monica Marcucci, Marina Moretti, Dermot Monaghan, Francesco Patemo, Gianmatteo Piazza, Alessandra Pischedda, Vincenza Profeta, Constant Verkoren, Damiano Sandri, and the Italian Ministry of Economics and Finance and Bank of Italy for helpful comments. All errors and omissions are our own.
} 
II. THE NATURE OF THE PROBLEM

A. Distribution of NPLs by Size, Region, and Sectors

B. Distribution of NPLs across Banks

C. Contributing Factors to the Build-up of NPLs

D. Output, Credit Default Risk, and Nonperforming Loans

E. Authorities' Actions

III. OBSTACLES TO NPL RESOLUTION

A. Economic Factors

B. Legal Factors

IV. OPTIONS FOR BRINGING DOWN NPLS

A. Recommendations for Reducing NPLs

B. Recommendations for Legal Reform

References $\underline{28}$

FIGURES

1.Nonperforming Loans $\underline{3}$

2. NPLs, Profitability, and Capital-Some Cross-Country Evidence $\underline{4}$

3. NPLs by Size, Sectors, and Region 1

4. Distribution of NPLs Across Banks, End-2014 $\underline{8}$

5. Default Risk 10

6. Key Drivers of Corporate Sector Default Risk; Sovereign Risk 12

7. Return on Equity 16

8. Enterprise Insolvencies $\underline{18}$

9. Enterprise Reorganizations

$\underline{18}$

\section{BOXES}

1. Modeling Elasticities Dynamically Using State Space Models

2. The 2015 Resolution of Four Lending Institutions

3. Public Guarantees and Backstop Fund

4. The Importance of Efficient Secured Transaction Laws

$\underline{26}$

\section{ANNEX}

Dynamic Bank-by-Bank Panel Regressions 


\section{INTRODUCTION}

Nonperforming loans (NPLs) in Italy appear to be stabilizing at high levels. They have tripled since the beginning of the crisis and, according to national definition, stood at $€ 360$ billion (18 percent of total outstanding loans) at end-2015.2,3 The problem is especially pronounced for so-called bad loans (sofferenze), which amount to more than half of total NPLs (Figure 1). Italian NPLs account for about a third of those in the entire euro area. Therefore, Italian NPLs are also of broader significance in the euro area.

A number of factors have played a role in accounting for the high NPLs. A combination of over-indebted corporates following the sharp crisis-related drop in output, banks generally low in capital buffers, a highly complex legal system of corporate restructuring and insolvency, lengthy judicial processes, and a tax system that until recently discouraged NPL write-offs have all contributed to high NPLs. And while NPLs appear to be stabilizing, their stock remains among the highest levels in the euro area and the pace of write-offs has not increased significantly.

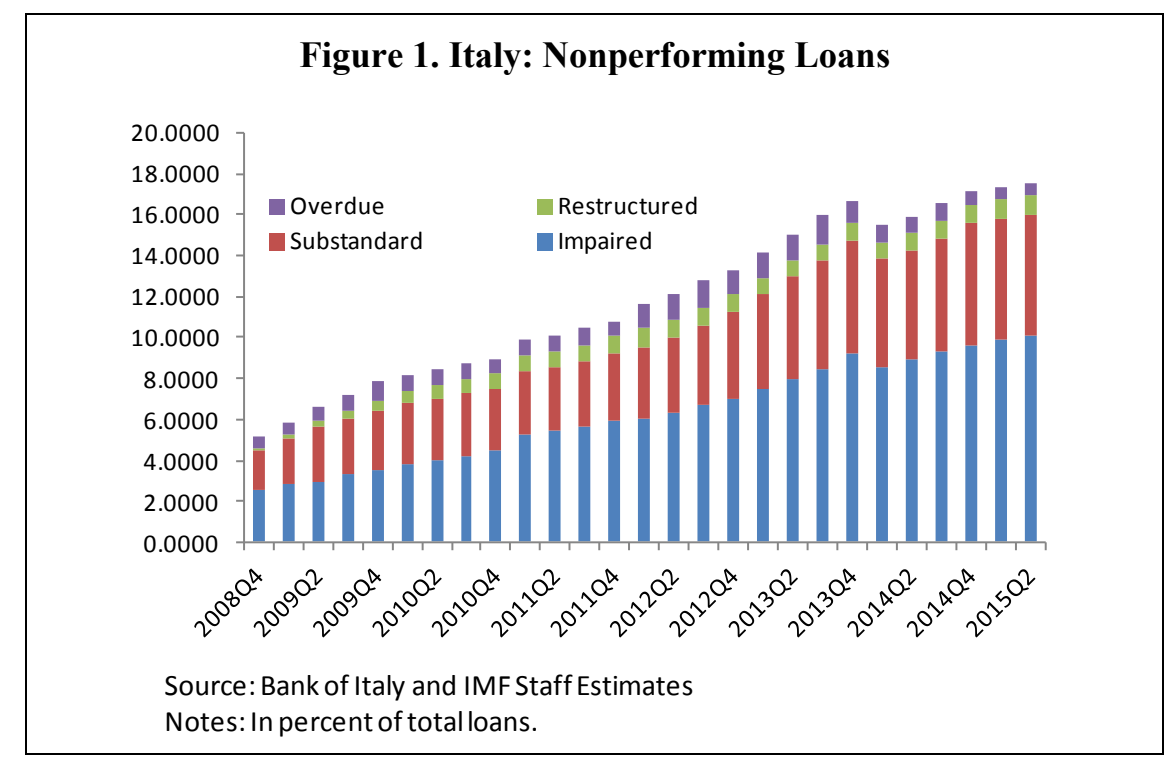

Banks have pursued a gradual process of writing off NPLs. This can be explained by several factors, including the high risk premia and ROEs targeted by investors. The cost of risk associated with loan losses and high administration costs for NPLs are not yet factored into lending margins and thus weigh heavily on bank profitability and hamper attempts to

\footnotetext{
${ }^{2}$ NPLs in Italy consist of four categories: impaired/bad debt or sofferenze (loans in a state of insolvency), substandard (incagli), overdue, and restructured.

${ }^{3}$ The 2014 asset quality review of the ECB/SSM of Italy's largest 15 banks, based on harmonized definitions of loan quality, asset classification, and provisioning, resulted in an aggregate nonperforming exposures ratio for the 15 analyzed banks of close to 22 percent. Two factors explain the difference: (i) ECB used a broader exposure definition that not only included loans (hence NPE vs. NPL); and (ii) the ECB's NPE is post-AQR, reflecting the findings from portfolio analysis.
} 
build up capital buffers (Figure 2). One might also consider there are provisioning gaps. Separately, corporate debt overhang has grown substantially especially during the global financial crisis. Hence, despite the availability of ample and cheap liquidity, banks have become much more cautious in extending new credit. For riskier corporates, and SMEs in particular, bank financing has become largely unavailable - or simply too expensive to be economically reasonable in an environment of persistent low growth. Given the absence of alternative sources of corporate financing in Italy, this has constrained investment and dragged down the economic recovery.

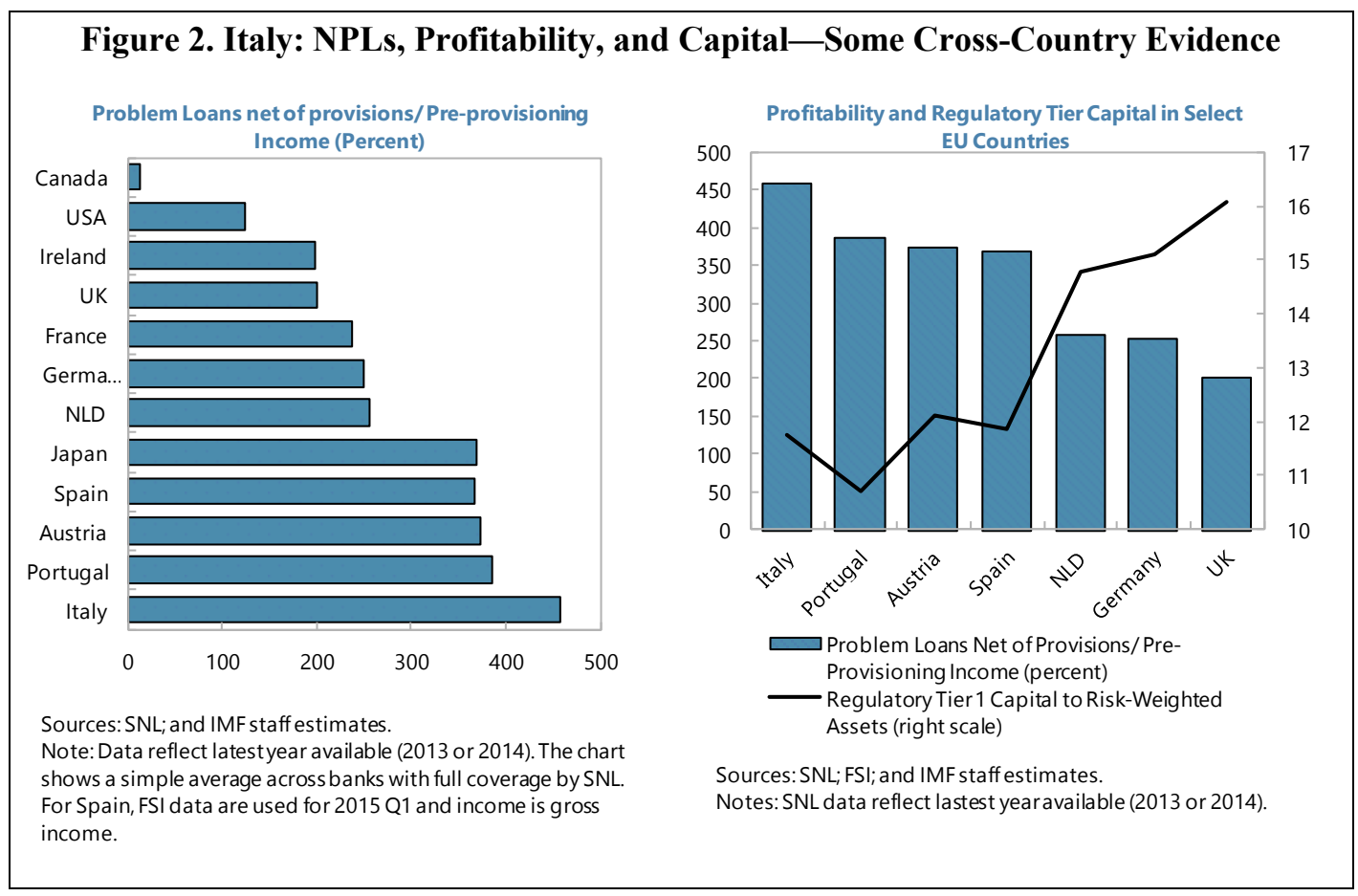

The authorities recognize the scale of the problem and have introduced several measures to deal with the NPL problem. These include improving the Italian insolvency system, fostering consolidation within the highly fragmented banking sector, and facilitating securitization and sale of NPLs. Many of these reforms, once fully implemented, are expected to yield benefits gradually over time.

This paper first provides a comprehensive analysis of the NPL problem in Italy. It investigates the distribution of NPLs by size, region, sectors, and across banks. It provides new econometric evidence on the factors that contributed to the build-up of NPLs in the past and the evolution over time of default risks of firms and banks. The paper then assesses obstacles to NPL resolution. The results suggest that the NPL problem in Italy has several specific features that need to be taken into account when devising a potential solution, including a pronounced regional dimension and concentration of NPLs in the corporate sector. The fact that NPL ratios are high, no matter the type of bank, underlines that asset quality is a general and system-wide problem. The crisis had a profound impact on the buildup of NPLs, which was exacerbated by bank-specific factors, and the prolonged 
recession led to higher default risks in corporate loans. The regression results demonstrate that cyclical developments are an important determinant of NPLs. The ongoing recovery in Italy may therefore help banks to reduce their stock of NPLs as suggested by the slight improvement NPL indicators as of end-2015. However, given the moderate inflation and growth outlook, banks could well struggle to grow out of their bad debt problems in a reasonable timeframe suggesting that additional measures may be needed.

The paper discusses several options to repair private sector balance sheets and support the recovery that acknowledge the strong interlinkages between Italian bank and corporate balance sheets. A potential solution needs to involve a broad-based clean up of bank balance sheets, decisive corporate restructuring, and the exit of unviable firms from the market. Elements of this strategy include economic, supervisory, and legal measures. To align incentives, long-standing problems in the corporate governance of Italian banks also need to be addressed. ${ }^{4}$

The paper complements and builds on the existing literature on NPLs in Italy. Jassaud and Kang (2015) is the paper most closely related to ours. It discusses the impediments to NPL resolution in Italy and outlines a strategy for fostering a market for restructuring distressed assets. Differently from that work, the present paper provides a detailed analysis of the nature of the problem, including through an analysis of NPLs by type of bank and a dynamic panel regression to examine factors contributing to their buildup, and state space models to illustrate how the influence of risk drivers has been changing over time. Our proposed strategy is more comprehensive in that it includes a detailed analysis of the insolvency system and reform options. For a number of European countries, including Italy, Aiyar and others (2015) also examine the scale and distribution of the NPL backlog, analyzing macroeconomic consequences of impaired bank balance sheets and institutional obstacles, and outline a comprehensive solution strategy. In contrast to this work, which takes a more European perspective, the present paper is able to provide a tailored, countryspecific strategy for Italy. Moreover, the paper goes into significantly more detail on legal and economic measures suitable for Italy to stimulate NPL resolution.

The remainder of the paper is structured as follows: Section II presents the nature of the problem, factors behind the buildup of NPLs, and a number of actions that the authorities have taken. Section III outlines the main obstacles to resolving NPLs. Section IV discusses some recommendations for tackling the NPL problem. Section V concludes.

\footnotetext{
${ }^{4}$ For a summary of specific challenges arising from the role played by foundations and cooperatives in Italian bank corporate governance, see Jassaud (2014).
} 


\section{The Nature of The Problem}

\section{A. Distribution of NPLs by Size, Region, and Sectors}

The NPL problem in Italy has several features that need to be considered when devising a potential solution (Figure 3). In terms of the total value of bad debt (impaired loans), more than 75 percent relates to loans above $€ 250,000$. However, in terms of the total number of borrowers, about 75 percent of bad debt relates to loans of less than $€ 75,000$.

About three quarters of bad debt are related to the corporate sector. Since the corporate sector in Italy comprises mostly small and medium sized companies (often with less than 10 employees), this may explain the prevalence of small loans noted above. ${ }^{5}$ The service sector and less technology-intensive sectors are most affected.

The problem has a pronounced regional dimension. Looking at all types of NPLs and all sectors of economic activity, there appears to be a north-south divide, especially in terms of bad loans to the corporate sector. While in early 2009, most regions had bad debt (sofferenze) ratios below 10 percent, by end 2014, most central and southern Italy regions saw their bad debt ratios increase above 20 percent.

Bank credit is to a large extent collateralized. While provisions stood at an average of 45.4 percent for total NPLs and 58.7 percent for bad loans as of December 2015, loans are also backed by collateral and guarantees, although court times to access them are very long. The authorities estimate that the real estate collateral and personal guarantees against bad loans amounted to $€ 87 \mathrm{bn}$ and $€ 37 \mathrm{bn}$ respectively at end-2015.

\section{B. Distribution of NPLs across Banks}

\section{Large banks hold the lion's share of NPLs, but NPL ratios are high across all types of} banks suggesting a system-wide problem (Figure 4). Specifically, the following patterns emerge from the data: most banks have NPL ratios between 15 and 20 percent, though there are a few banks (especially smaller ones) that face extremely high NPL ratios. There is no clear correlation between NPL ratios (in percent of total loans) and bank size. As of December 2014, the five largest banks in Italy accounted for two-thirds of total bad debt and NPLs. However, large cooperative banks (banche popolari) faced the highest NPL ratios with the lowest coverage ratio at end-2014. ${ }^{6}$ This is consistent with the findings from the IMF's 2013 Financial Sector Assessment Program.

\footnotetext{
${ }^{5}$ Of course, if most loans had been to households, the prevalence of small loans would likely have been even higher.

${ }^{6}$ This is consistent with Jassaud (2014), who concludes that owing to their corporate governance structure, large cooperatives tend to display lower buffers and weaker asset quality metrics than the system average.
} 
Figure 3. Italy: NPLs by Size, Sectors, and Region

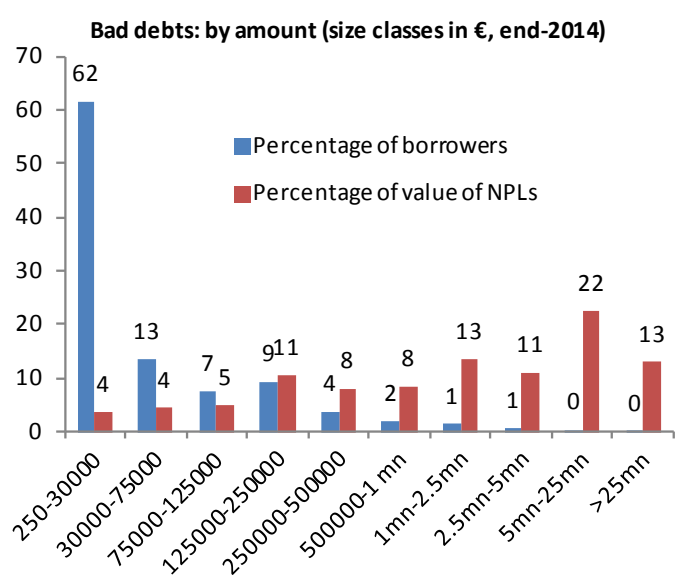

Bad debts: used margin - by segment of economic activity (in percent of total bad debt, end 2014)

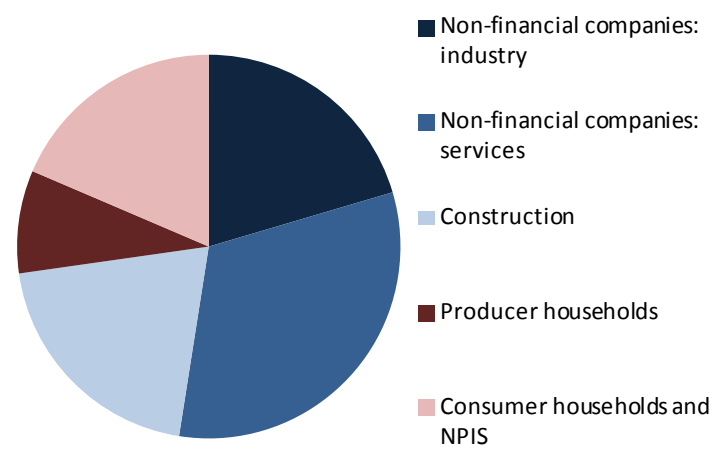

Bad debts (end-2014, percent of total loans by economic activity)
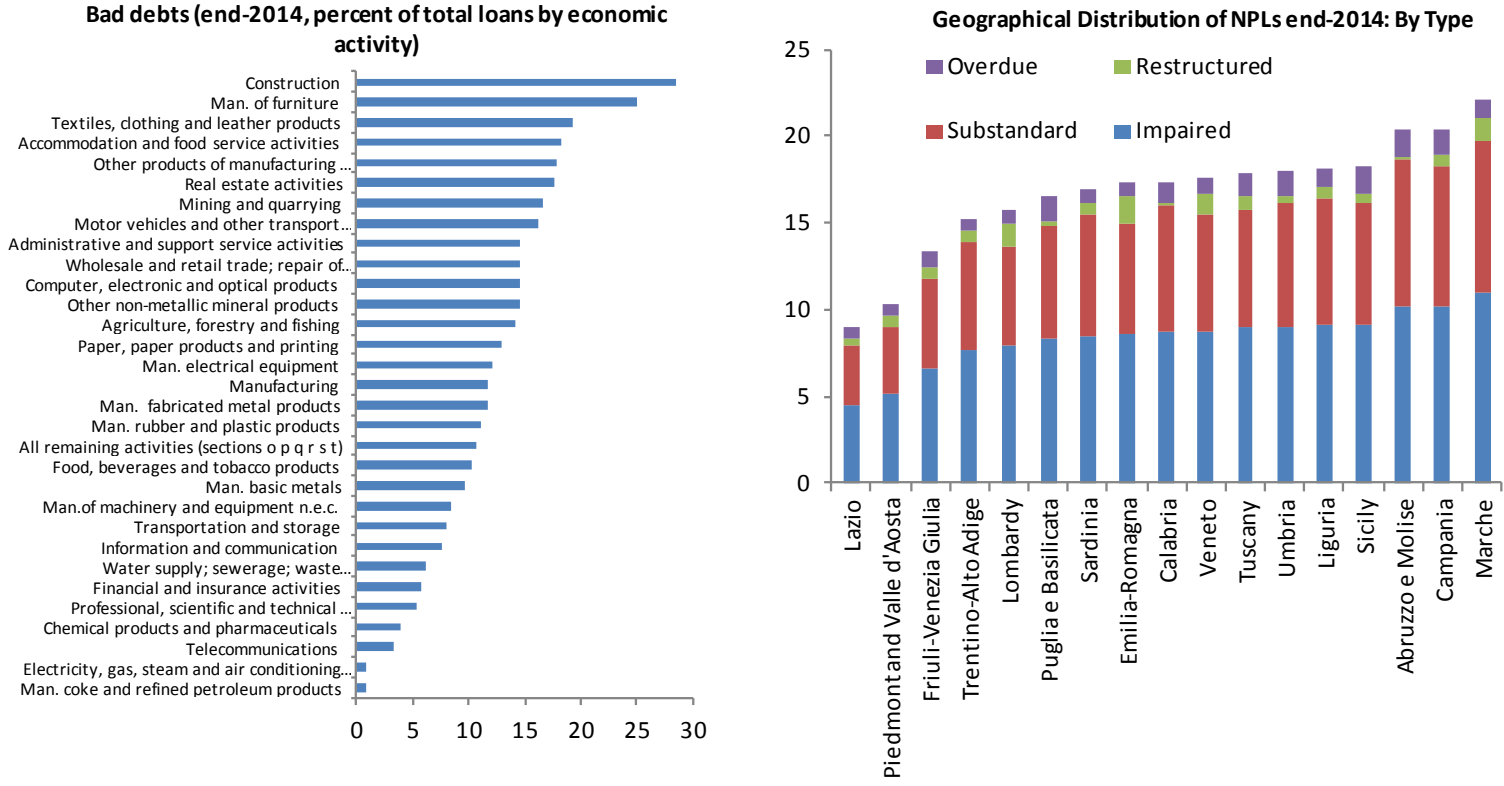

Bad Debts by region (percent of total loans, NFCs, Q1-2009)

Bad Debts by region (percent of total loans, NFCs, end-2014)
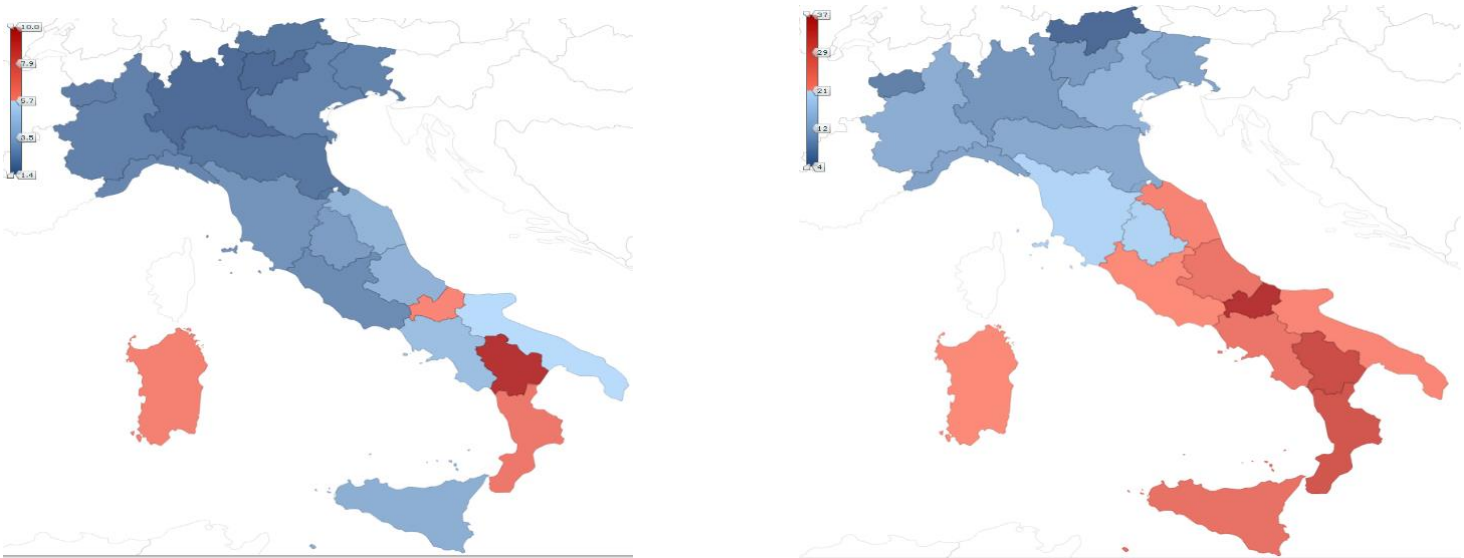

Sources: Bank of Italy; and IMF staff estimates. 
Figure 4. Italy: Distribution of NPLs Across Banks, End-2014
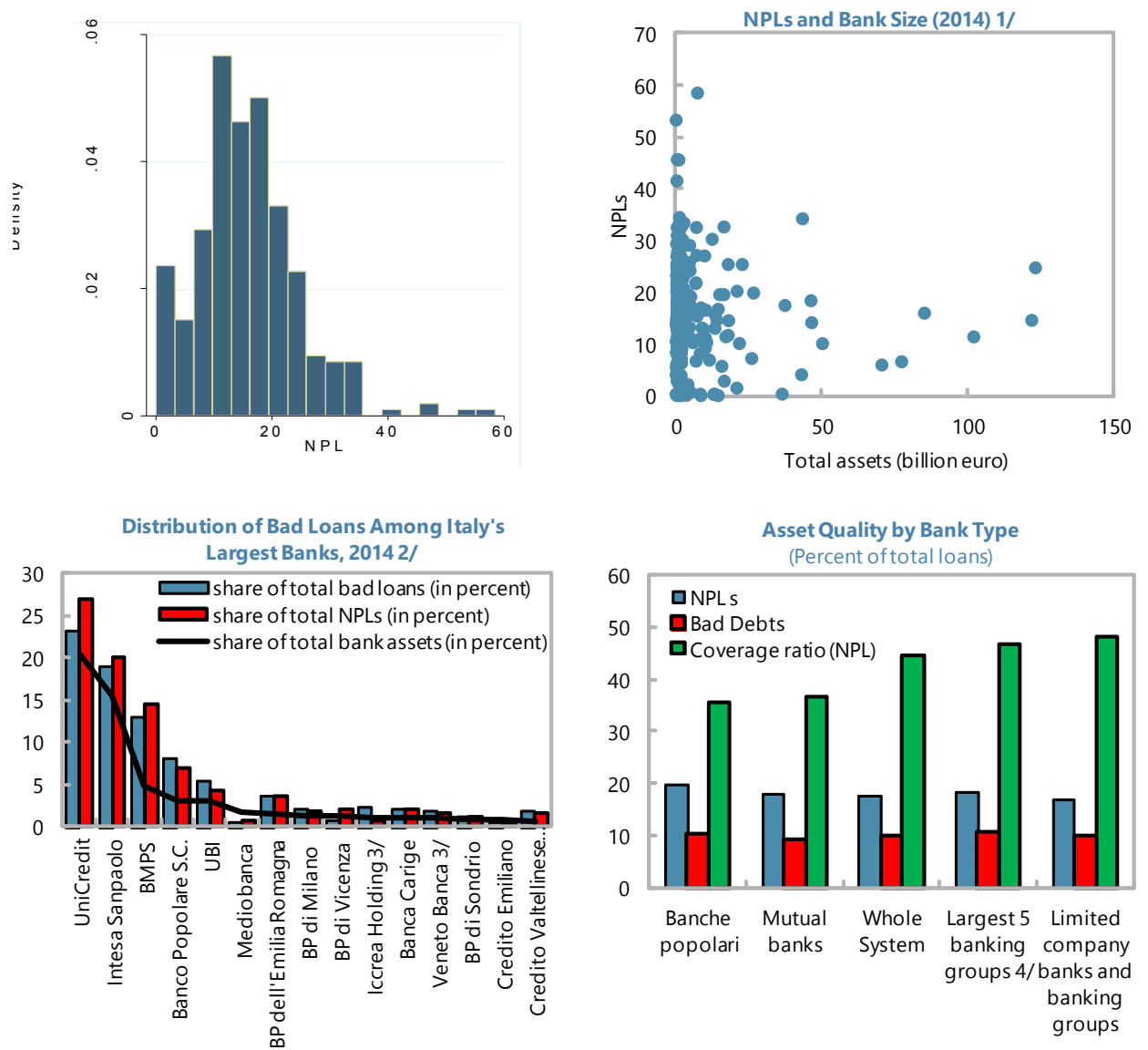

Sources: SNL; Bank of Italy; and IMF staff estimates.

1/ 2014 data. NPLs are in percent of total gross loans. Full SNL sample of 402 Italian banks.

2/Total system wide bad loans and NPLs based on from supervisory returns data from Bol.

Data for bad loans from SNL are net of provisions.

3/ bad loans and problem loans from SNL based on 2013 data.

4/ largest five banking groups by total assets as of December 2014.

\section{Contributing Factors to the Build-up of NPLs}

Using a dynamic panel regression, we differentiate between bank-specific and

macroeconomic factors. The econometric methodology follows Klein (2013), who investigates NPLs in Central, Eastern and South-Eastern Europe. More specifically, we run fixed effects and Generalized Method of Moments (GMM) regressions of NPLs (problem loans in percent of total gross loans) on various macroeconomic variables common to all banks (lagged inflation, NEER percentage change, lagged real GDP growth, lagged percentage change in house and stock prices), as well as bank-specific variables (lagged equity/assets ratio, lagged ROE, lagged loan 
growth and lagged Tier 1 ratio). ${ }^{7}$ We include both bank-specific and macroeconomic variables since the past literature suggests that both have played a role in NPL buildup in other countries (Klein, 2013). ${ }^{8}$ To have data for a number of years, we use SnL data for 62 banks for which comprehensive time series data since 2005 are available. To check the robustness of the results, we also perform the same regression with the larger sample of banks for which SnL provides summary data. The results are shown in Annex A. ${ }^{9}$

\section{The analysis suggests that both bank-level and macroeconomic factors have affected} banks' asset quality. Lower profitability in the past is associated with higher NPL levels. ${ }^{10}$ And higher lending in the past - measured by (lagged) loan growth - is related with higher NPLs, indicating that faster loan book expansion on average results in worse asset quality. A number of macroeconomic variables are significant as well. For instance, lower growth, exchange rate appreciations, and falling house prices are significantly associated with higher NPLs. ${ }^{11}$ Overall, the results show that the recession, which was of exceptional duration and intensity, had a profound impact on banks' asset quality, which was exacerbated by bank-specific factors. The firming up of the ongoing incipient recovery might help banks to reduce NPLs faster, as suggested by the recent stabilization in NPLs. However, given the moderate growth and inflation outlook, additional measures are likely to be needed.

The prolonged recession led to higher default risk for large corporates and banks, which are typically low-default portfolios (Figure 5, left chart). In particular, corporate and bank default probabilities peaked in mid-2012. And while default probabilities have come down substantially since then, NPLs continued to rise until 2015Q3 (Figure 5, right chart).

\footnotetext{
${ }^{7}$ Further work on this could usefully examine the role of government bond spreads. However, endogeneity problems could arise and suitable instruments would have to be found. Moreover, ideally, bank-level data on lagged loan growth should be included, but these data are not available from $\mathrm{SnL}$.

${ }^{8}$ To correct for potential biases associated with feedback effects among variables (e.g., house prices and growth) and check the robustness of fixed effects regression results, we also used a system GMM approach for estimation. We include year dummies in the regressions.

${ }^{9}$ While SnL currently provides some summary data for 402 Italian banks that are in operating status, and full coverage data for 62 banks, for some banks there are very few time series observations, which is why in the regressions the number of banks is somewhat smaller than those numbers (326 and 57).

10 The causality between RoE and NPLs could be two ways as higher NPLs also worsen banks' equity position. This is why all independent variables are lagged.

${ }^{11}$ House prices are only significant in the fixed effects regression, not when performing system GMM.
} 
Figure 5. Italy: Default Risk

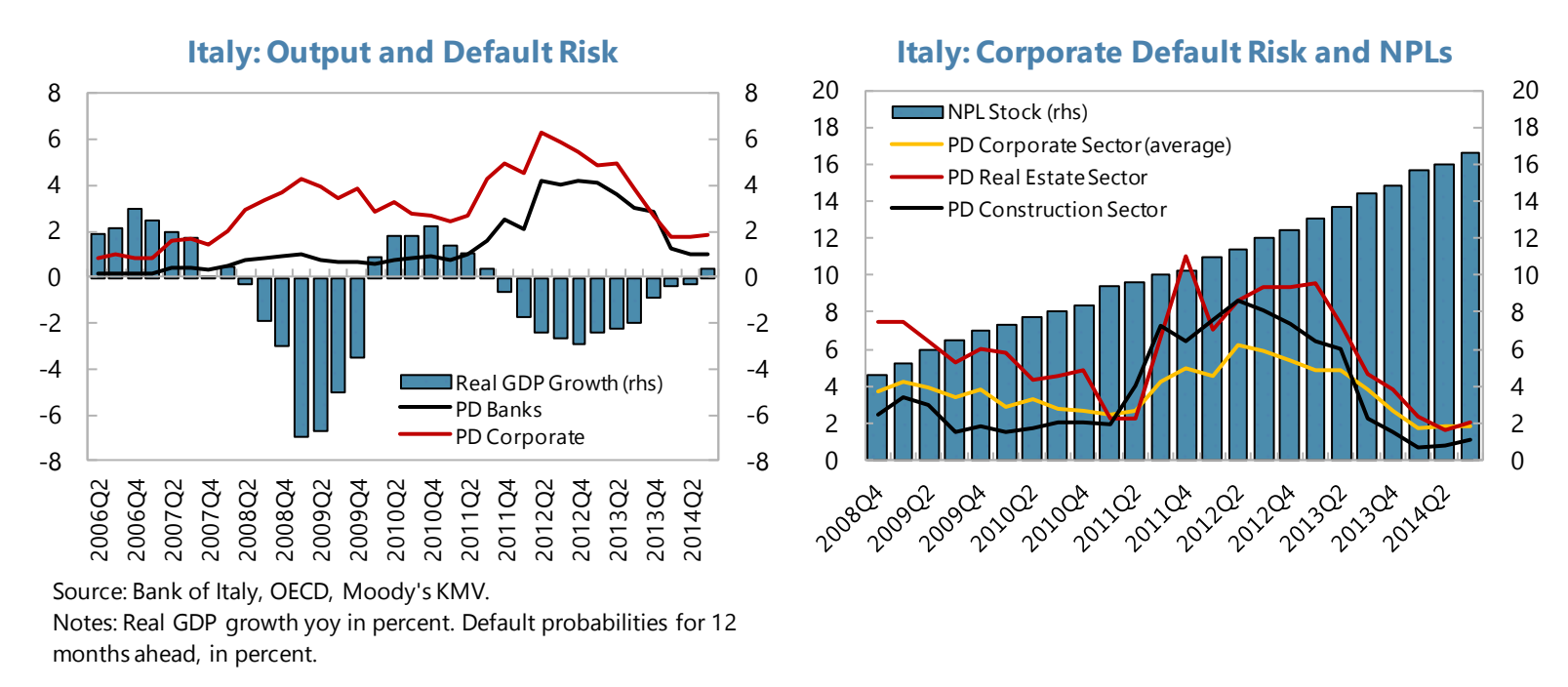

\section{Output, Credit Default Risk, and Nonperforming Loans}

In turn, corporate sector default risk has been driven mostly by the interest rate environment and real activity. A macro-financial dynamic state space model (DSSM), which is described in Box 1, illustrates how the dynamics have changed over the past few years (Figure 6).

The estimates suggest that (1) further output losses would fuel credit risk considerably more than in the past; and (2) higher interest rates would now have a much more substantial impact on corporates than in the past. Similarly, increases in interest rates would negatively impact the market value of banks' holdings of Italian sovereign assets, as the volume of sovereign bonds in banks' books has risen substantially. ${ }^{12}$

\footnotetext{
${ }^{12}$ However, Italian banks do have significant unrealized capital gains from sovereign bond holdings. See BoI Financial Stability Report April 2015.
} 


\section{Box 1. Modeling Elasticities Dynamically Using State Space Models}

Dynamic State Space models (DSSM) allow modeling nonlinearities in the functional relationship between variables, and describing explicitly structural changes over time. This is an important property as the influence of different macrofinancial factors on credit risk typically changes during periods of financial distress ("correlation breakdown"). Second, the measurement of credit risk variables generally tends to be rather blurred, and it is unlikely that the default or default probability time-series at hand can give the true risk. The DSSMs helps push imprecise measurements toward the true values, thereby increasing precision.

A regression with time-varying coefficients can be represented by

$$
y_{t}=\beta_{0, t}+\beta_{1, t} x_{1, t}+\ldots+\beta_{n, t} x_{n, t}+\varepsilon_{t}=\beta_{0, t}+\sum_{i=1}^{n} \beta_{i, t} x_{i, t}+\varepsilon_{t}
$$

Alternatively, the State Space form can be chosen

$$
\begin{gathered}
\theta_{t+1}=F_{t+1} \theta_{t}+v_{t+1} \\
y_{t}=H_{t}^{\prime} \theta_{t}+w_{t}
\end{gathered}
$$

where $\theta_{t}$ denotes the regression coefficients in the state vector $\left(\beta_{0}, \beta_{1}, \ldots, \beta_{n}\right)^{\prime}, H_{t}^{\prime}=\left(1, x_{1, t}, \ldots, x_{n, t}\right)$ the $n$ regressors, and $F_{t}$ is the state transition matrix from time $t$ to $t+1$. The variance of the multidimensional noise vectors $v_{t}$ and $w_{t}$ are driven by the time-variant matrices $V_{t}$ and $W_{t}$. If the variances in $V_{t}$ are larger than zero, the coefficients become time-varying. ${ }^{1}$ Hence, for the dynamic multivariate state space regression model, both $V_{t}$ and $W_{t}$ are nonzero. ${ }^{2}$ The dynamic coefficients can be estimated using the Kalman Filter, a set of recursion equations determining, conditional on the information available at time $t$, optimal estimates of the state vector. The estimation is performed recursively:

$$
\begin{gathered}
\hat{y}_{t}=H_{t}^{\prime} \hat{\theta}_{t \mid t-1} \\
\varepsilon_{t}=y_{t}-\hat{y}_{t} \\
\hat{\theta}_{t \mid t}=\hat{\theta}_{t \mid t-1}+\varepsilon_{t}\left[P_{t \mid t-1} H_{t}\left(H_{t}^{\prime} P_{t \mid t-1} H_{t}+R_{t}\right)^{-1}\right] \\
\hat{\theta}_{t+1 \mid t}=F_{t+1} \hat{\theta}_{t \mid t}
\end{gathered}
$$

${ }^{1}$ Since $W_{t}>0$, the state space model also includes the correlation patterns between the variables in $H_{t}$.

${ }^{2}$ The signal-to-noise ratio $V / W>0$ indicates how adaptive the coefficients are. 


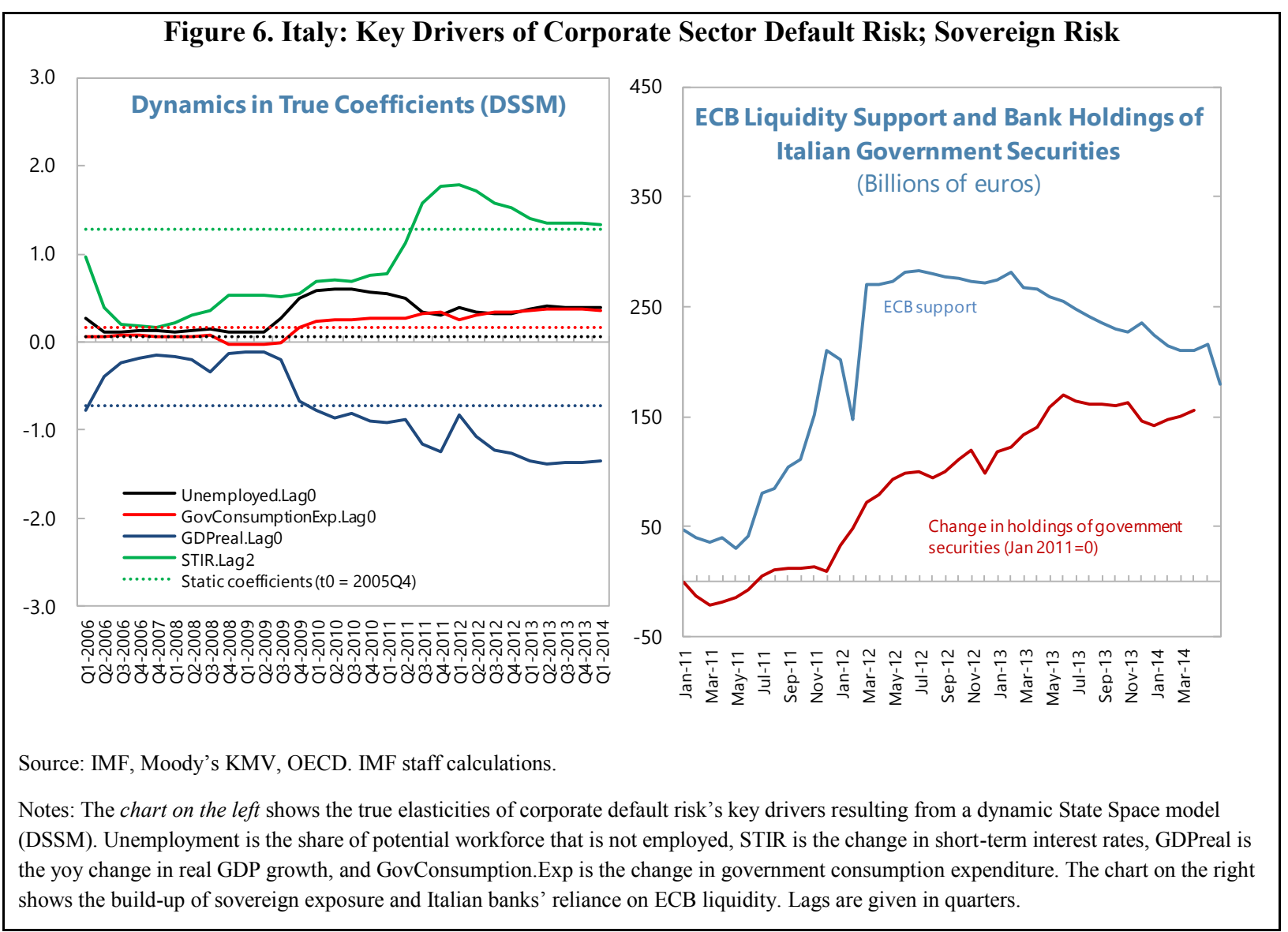

\section{E. Authorities' Actions}

The authorities have taken a number of measures to address the NPL problem. These include the following:

- In March 2015, both houses of parliament approved a decree to reform the governance of cooperative banks that had scored weakly in the FSAP. The reform removes key structural inefficiencies such as one vote per head and limitations on the size of individual shareholdings. The reforms are aimed at promoting consolidation and balance sheet cleanup, and improving profitability.

- In April 2015, a protocol of intent was signed by the Ministry of Economy and Finance and ACRI (the association of foundations) to foster the self-reform of the banking foundations. Foundations have committed among other things to adopt appropriate portfolio diversification to limit risk concentration and their participation in the capital of banks. 
- In August 2015, the Italian government enacted a decree law containing measures that help banks offload NPLs. ${ }^{13}$ The decree includes a number of measures, including (1) improving the insolvency law to shorten the duration of procedures and increase both the survival of distressed enterprises and the creditors' recovery; (2) accelerating the fiscal deductibility of provisions by allowing banks to deduct loan losses from their tax bill within a year instead of five; (3) changes in civil procedures to strengthen debt enforcement; and (4) reforms to civil justice, including streamlined enforcement procedures, increased use of electronic processes and an increase in staff (through hiring from other administration areas).

- In November 2015, the authorities resolved four small banks (Box 2).

- In late January 2016, the Italian authorities agreed with the EC on a mechanism called GACS to securitize and guarantee NPLs (Box 3). The agreement appears to have put to rest for now the long-running discussion with the EC on setting up an asset management company (AMC), owing to EU state aid concerns.

- In February 2016, the Italian government approved a reform of small mutual banks, pushing them to consolidate under joint-stock (holding) companies with at least $€ 1$ billion in equity, in a bid to strengthen the fragmented local banking sector. The hope is this will create a single group in the next 18 months, the deadline for mutual banks to implement the reform.

- In April 2016, Italy's largest banks together with nonbank financial institutions and banking foundations, created a fund called Atlante (Box 3) that, so far, has raised $€ 4.25$ billion. The aim was to backstop capital increases of banks and purchase non-investment grade tranches of NPL securitizations (so as to reduce the gap between the prices that banks want to sell at and those sought by investors).

- In May 2016, a decree-law introduced out-of-court enforcement mechanisms for commercial lending relationships secured by immovable collateral; a new framework for non-possessory security interests over movable assets; a registry of enforcement and insolvency procedures; and other improvements to enforcement and insolvency procedures.

In addition, the Bank of Italy has also recently launched a new periodic survey to gather detailed information on the stock of bad debts, the related collateral and guarantees, and recovery procedures.

\footnotetext{
${ }^{13}$ Decree Law 83/2015, converted into Law 132/2015.
} 


\section{Box 2. The 2015 Resolution of Four Lending Institutions}

On November 22, 2015, the Bank of Italy (BoI) and the Italian government announced plans to resolve four small Italian credit institutions (Banca delle Marche, Banca dell'Etruria e del Lazio, Cassa di Risparmio di Chieti, and Cassa di Risparmio di Ferrara). The total market share of these banks comes to about 1 percent of system-wide deposits. They had been under BoI's extraordinary administration. The total rescue cost amounted to $€ 3.6$ bn. ${ }^{1}$

The resolution was consistent with the EU Bank Restructuring and Resolution Directive (BRRD), which was transposed into Italian law on November, $162016 .{ }^{2}$ However, the bail-in tool of the BRRD, which requires bailin of 8 percent of eligible liabilities, became mandatory only by January 1,2016. To make the case for a resolution (and not a liquidation), the authorities argued that the four banks play an important regional role and that it was important to fully protect household and firms' deposits.

The solution, which had to be compliant with EU state aid rules and did not involve public funds, consisted of the following elements:

- Bail-in of equity and subordinated debt: $€ 798 \mathrm{mn}$ losses were imposed on junior bondholders, of which around half were held by retail investors.

- Each of the four banks was split into "good or bridge banks"-which took over all assets except bad debts (sofferenze) and all liabilities except those bailed in —and a "bad bank" containing bad debt.

- A single bad bank was created to take on the bad loan assets of all four banks. Bad loans were written down to $€ 1.5 \mathrm{bn}$ from an original balance-sheet value of $€ 8.5 \mathrm{bn}$, or a valuation of $171 / 2$ percent. They will either be sold on the private market or managed directly to recoup the greatest amount possible with the proceeds going to the Resolution Fund.

- The Resolution Fund's financial outlays of $€ 3.6$ bn were distributed as follows:

○ $€ 1.8$ bn was injected into the "good banks" to arrive at a target CET1 ratio of 9 percent.

○ $€ 1.7$ bn was used to write down most of the banks' bad debt, and set up the bad bank.

○ $€ 140 \mathrm{mn}$ was used to form the minimum capital for the bad bank.

- The cost of the rescue was borne by the Resolution Fund. The liquidity required for the rescue was advanced by three major banks (Intesa, Unicredit, and UBI).

- The good banks kept the original brand name, adding the suffix "Nuova." The banks will temporarily be administered by BoI, and the bridge banks are to be sold quickly, in a transparent and nondiscriminatory manner, to the highest bidder. The proceeds of the sales would be retained by the Resolution Fund.

Following the rescue and the bail-in, there was a large public uproar related to the bail in of junior bonds held by retail investors. The banks therefore voluntarily set up a fund that will be attached to the national deposit insurance scheme to compensate a large number of retail investors of the four banks that were bailed in. Since this fund is based on voluntary contributions by banks, it does not constitute state aid.

${ }^{1}$ See also information released by BoI: https://www.bancaditalia.it/media/approfondimenti/2015/info-soluzionecrisi/index.html?com.dotmarketing.htmlpage.language $=1$.

${ }^{2}$ Legislative Decree 180/2015. 


\section{Box 3. Public Guarantees and Backstop Fund}

The Italian authorities recently launched or supported two initiatives to support banking system stability. Garanzia Cartolarizzazione Sofferenze (GACS) is a mechanism to guarantee investment-grade NPL securitization transactions. The investment fund Atlante is aimed at backstopping the capital issuance of smaller (distressed) banks and, possibly, buying junior tranches of NPL securitization transactions.

\section{GACS}

In January 2016, the Italian authorities agreed with the EC on a mechanism that provides government guarantees for the securitization of bad loans. It takes the form of multiple special purpose vehicles (SPVs), one for each participating banks. The scheme would focus only on sofferenze loans (bad loans), and exclude other impaired exposures such as past due loans and loans classified as "unlikely to pay." Banks can set up SPVs to move their bad loans at market values, which would then be securitized. Furthermore, banks can choose to buy public guarantees for the investment-grade rated senior tranches, and sell them in the retail market. Owing to the specific risk-return profile, equity and junior notes, on the other hand, are expected to be attractive to private investors and hedge funds in particular. The public guarantee would be priced at market terms, based on credit default swaps on Italian issuers with similar risk profiles to the loans in question. The price of the guarantee increases over time, creating an incentive to accelerate NPL recovery (first three years based on three-year CDS, third until fifth year on five-year CDS and after five years based on sever-year CDS). Since the guarantees are priced at market terms based on expected losses, they do not qualify as public support subject to EC approval under EU State aid regulations. The full impact of the agreed mechanism is unclear at this moment, but market participants expect it to have a positive albeit modest impact as the transfer price for securitizing NPLs with government guarantees via GACS does not seem sufficient to close the 15-20 basis points pricing gap. GACS is widely expected to close this gap by around $2-3$ percentage points.

\section{Atlante}

Atlante is being funded by the largest Italian banks, nonbank financial institutions and banking foundations, with an 8 percent minority stake held by the largely publicly-owned Cassa Depositi e Prestiti (CDP). The fund is to act as a backstop facility for ongoing banks' capital increases, and designed as a buyer of last resort as it can buy non-investment grade tranches of NPL securitization transactions. The fund can also invest in real estate assets.

By April 29, 2016 Atlas managed to collect $€ 4.25$ billion, of which UniCredit SpA and Intesa Sanpaolo Spa each would take a $€ 1$ billion stake in the fund. Atlante provided $€ 1.5$ billion for the capital increase of Banca Popolare di Vicenza, which had previously been guaranteed solely by UniCredit SpA. It will do the same for Veneto Banca to the tune of $€ 1$ billion. The regulatory treatment of banks' equity investments in Atlante, i.e., whether the amount invested will have to be deducted from regulatory capital, is yet to be determined by the ECB and national authorities, however. If the contributions to Atlante were deducted from regulatory capital, it would leave funding banks with a smaller capital buffer in excess of its prudential capital requirement.

\section{ObSTACLES To NPL Resolution}

\section{A. Economic Factors}

\section{Uncertainties in recovery values can result in substantial gaps between book and market values, creating disincentives for banks to write-off NPLs. Reducing such uncertainties requires more conservative approaches to provisioning. A thin market for NPLs introduces a liquidity premium, which can result in heavily discounted transfer prices upon sale. ${ }^{14}$ Weak}

\footnotetext{
${ }^{14}$ Recent research by the BoI (Ciavoliello and others, 2016) highlights two reasons for the substantial gap between book and market values that can account for the entire difference. Investors in NPLs demand a high rate of return, partly because they generally have less financial leverage than banks. This return is used to discount the expected
} 
profitability and, for a number of banks, low capital buffers provide only limited space for balance sheet clean up. NPLs weigh heavily on bank profitability (Figure 7) and the already thin profit margins make it difficult for banks to digest additional loan loss impairments or sell portfolios in an illiquid market (see also Jobst and Weber, forthcoming).

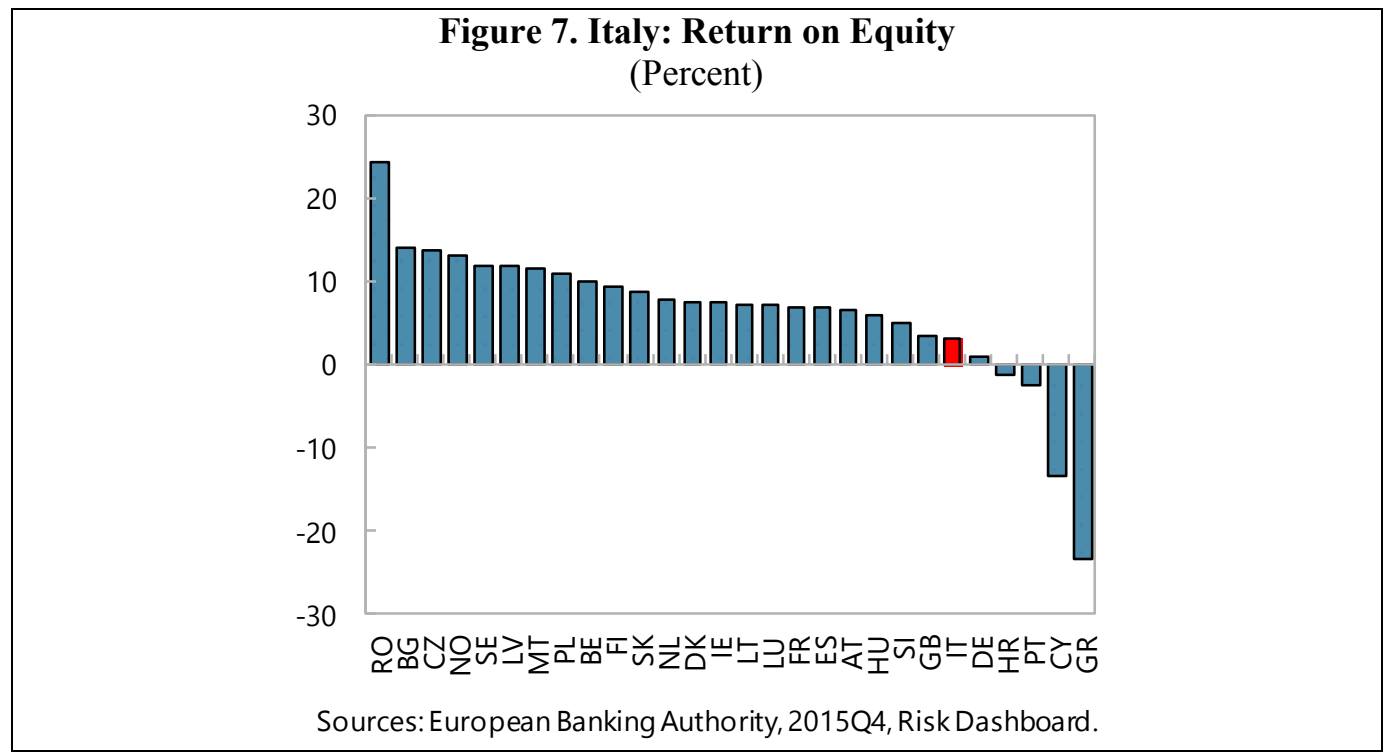

Relationship lending has played an important role and could also be hindering swifter progress on NPLs. It is an important element of many cooperative and regional banks, and has arguably helped many embattled nonfinancial corporations survive the deep recession suffered by the Italian economy. At the same time, related-party lending has likely contributed to the build-up of problem loans in medium-sized and small credit institutions, which was one of the reasons behind the recent reforms of the cooperative banks. It also makes it more difficult to resolve NPLs.

The previous tax treatment penalized Italian banks that tackled problem loans more aggressively. Until the 2013 reform, write-offs were only tax deductible in the state of insolvency. Tax deductibility of loan-loss provisions from taxable income was limited to 0.3 percent of outstanding loans, with the remaining part treated as a deferred tax asset (DTA). DTAs were deductable from taxable revenues over a period of 18 years. ${ }^{15}$ This cap constituted a clear disincentive to provisioning. Since 2013, provisions and write-offs can be deducted in equal installments over five years, and with a higher tax rate. While this approach is still more

cash flows from NPLs (banks adopting the IAS/IFRS international accounting principles instead use the original effective interest rate on the assets, which is usually much lower) and results in a lower NPL price. Banks, as required by international accounting principles, include the indirect costs of managing NPLs in their financial statement of the year in which they are incurred, whereas potential acquirers deduct them immediately from the value, thus reducing the purchase price.

${ }^{15}$ This has also contributed to the build-up of Deferred Tax Assets (DTAs) in Italian banks, as remaining provisions could be deducted in equal installments over a period of 18 years (and at a lower net present value). 
restrictive than in other countries, incentives for accelerated write-off have increased. ${ }^{16}$ As of end-2014, DTAs not deducted from capital amounted to $€ 43$ bn. As of August 2015, write-offs are now immediately tax deductible.

In the past, insufficient guidance on accounting under IFRS led to slow NPL write-offs. IAS 39 does not define when and how defaulted loans are to be written off. Since the current accounting regime under IFRS does not include clear write-off rules, banks (including Italian credit institutions) apply a de-recognition rule (loan cancellation). This practice, however, was supposed to be applied only under certain conditions (like asset transfer or if a bank no longer tries to collect the overdue amounts), and not as a general practice.

Smaller banks have limited experience and capacity to deal with NPLs. While the largest Italian banks have been able to dispose of NPLs, invest in internal NPL management, and set up decentralized AMCs, the medium and small-sized banks have struggled to bring down NPLs. ${ }^{17}$ These banks lack risk management capacity, NPL management experience, and access to distressed debt markets.

The sectoral composition of NPLs makes the problem more difficult. Unlike in other countries, where NPLs were concentrated in the real estate sector and therefore were relatively easy to value, Italian NPLs are mostly commercial including a large number of micro and small enterprises, and are very heterogeneous.

\section{B. Legal Factors}

From a legal point of view, there are two main methods that are generally used to deal with nonperforming loans: the contractual method (either by renegotiating loans or by selling them) and the enforcement method (which can be implemented by individual enforcement, as in mortgage foreclosure, or by collective enforcement, as in an insolvency process). Although these two main methods may seem independent, the enforcement method has an important influence on the feasibility and effectiveness of the contractual method. The more effective enforcement is, the more effective the contractual methods to deal with NPLs will be. In other words, effective enforcement mechanisms incentivize the development of a market for NPLs, as the value and attractiveness of NPLs increases. ${ }^{18}$

\section{The Italian insolvency regime is characterized by its high complexity, providing multiple procedures and debt restructuring tools that appear to lack coordination and anified}

\footnotetext{
${ }^{16}$ For further details, see http://www.bancaditalia.it/pubblicazioni/note-stabilita/2014-0001/index.html.

${ }^{17}$ In fall 2014, UCG sold $€ 2$ bn in NPLs in the market. And in February 2015, the bank announced the sale of its entire participation in UniCredit Credit Management Spa, including a $€ 2.4$ bn NPL portfolio, to a private AMC (Fortress/Prelios) aimed at both liquidation (bad debt) and NPL management (other NPLs), in particular for SME NPLs. Net of provisions, bad debts at UCG stood at about $€ 36$ bn in 2013.

${ }^{18}$ As shown by Ciavoliello and others (2016), the difference between bid-ask prices is proportionate to the length of the recovery procedure (judicial or extra-judicial). A two-year reduction in recovery times would entail a market price increase of NPLs of approximately 10 percentage points.
} 
vision (see Garrido 2016). The system is divided between a generally applicable insolvency regime, and special regimes that apply to large enterprises, small enterprises and individuals, and enterprises subject to special supervisory regimes. Even within the general regime, there are a number of procedural avenues and options whose interplay and coordination is not always clear. Procedural complexity could be an explaining factor of the high litigiousness, and it is also likely that it assists debtors in implementing delaying strategies.

The bulk of distressed enterprises in Italy can use different debt restructuring procedures, formal reorganization, and liquidation. ${ }^{19}$ However, there are significant disincentives for the use of some of the mechanisms: the procedures for informal or hybrid debt restructuring (piani di risanamento and accordi di ristrutturazione) do not offer enough flexibility, as their goal is often to achieve full payment to creditors. ${ }^{20}$ The rigidity of debt restructuring mechanisms and the inability to bind dissenting creditors result in a loss of efficiency of debt restructuring procedures. In contrast, formal insolvency procedures (concordato preventivo and fallimento) can bind minority creditors and allow for more flexible solutions, although a recent reform has included a limit to the haircut unsecured creditors may have to accept in certain plans. Informal debt restructuring agreements cannot be easily transformed into formal reorganization plans in the current system. In addition, there are obstacles to adopting advanced restructuring solutions, such as debt/equity swaps, because of shareholders' interference and the respect of shareholders' preemption rights. The 2015 reform has sought to address this problem by giving the courts the power to appoint a special administrator replacing the debtor's management, but the law has not removed the powers of the shareholders' meeting to decide on the company's capital structure.

The number of insolvency cases has increased substantially since the onset of the crisis. In 2014, enterprise bankruptcies surpassed 15,000 cases (+10.7 percent in comparison with 2013) (Figure 8). It is estimated that more than 82,000 enterprises have been liquidated in insolvency processes since 2008, with an associated loss of about a million jobs (Cerved 2015). By contrast, enterprise reorganizations declined by 20 percent in 2014 (Figure 9). ${ }^{21}$ For 2015, the figures

show a stabilization in the number of enterprise insolvencies (at 14,700 cases) and a further reduction in reorganizations.

\footnotetext{
${ }^{19}$ Large enterprises (with more than 200 employees) can use special procedures (amministrazione straordinaria, in its so-called versions "Prodi" and "Marzano"). Small enterprises are not subject to general insolvency law, and fall within the scope of the personal insolvency regime. Enterprises subject to special supervisory or regulatory regimes have their own liquidation procedure (liquidazione coatta amministrativa).

${ }^{20}$ The survey conducted by Carpinelli et al. (2016) shows that banks make extensive use of restructuring agreements. It is difficult to conclude, however, about the effectiveness of these agreements, since there could be a selection bias (using these agreements only for companies in minor distress), and the restructuring agreement could be the start of a sequence of restructuring attempts, ending in liquidation.

${ }^{21}$ This decline in reorganizations was probably the result of the reintroduction of stricter requirements for the initiation of reorganization procedures, as discussed in the text. The spike in these procedures that was observed in previous years has been attributed to the leniency of the access requirements and the use (and abuse) of the procedure by debtors with the purpose of delaying enforcement.
} 


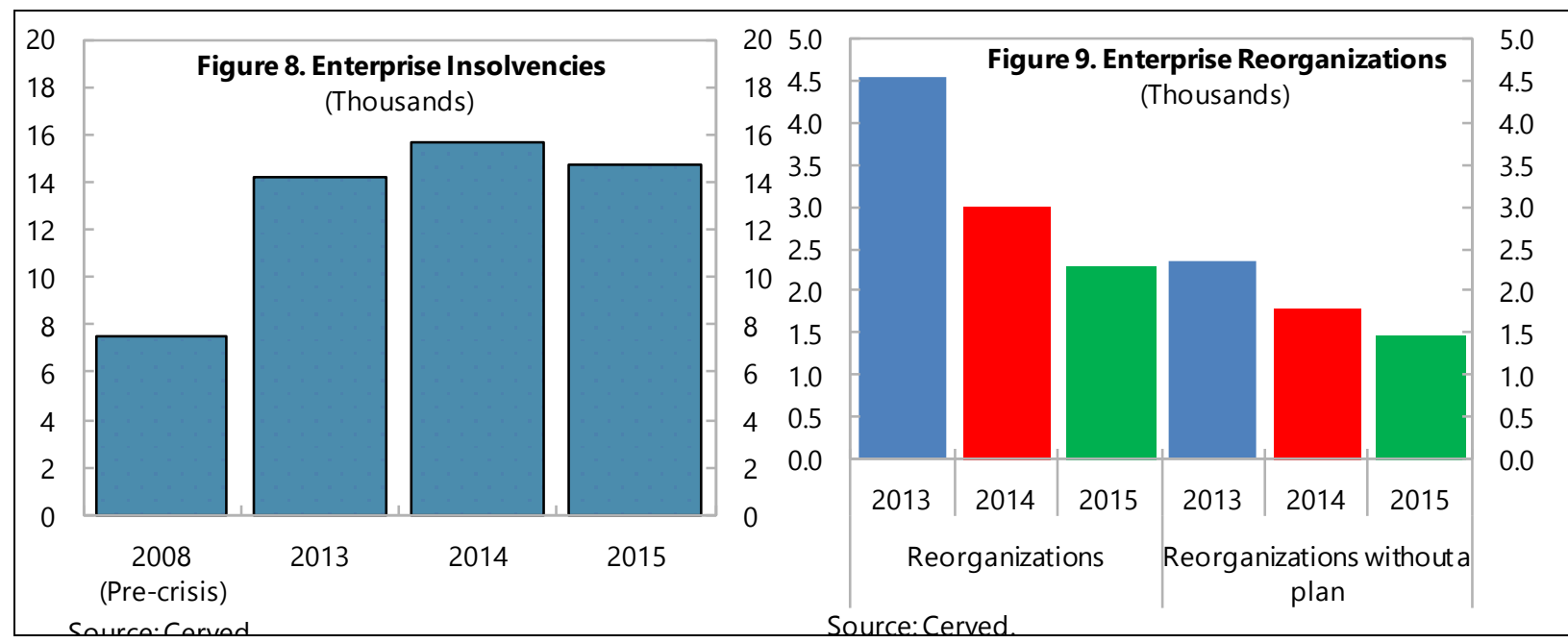

Insolvency procedures have suffered long delays. According to statistics furnished by the Italian Ministry of Justice, liquidations have on average lasted more than eight years, with preferential and unsecured creditors recovering 29 and 6 percent of claims, respectively.

Apart from the general inefficiency of civil courts, specific bottlenecks in insolvency procedures have contributed to the delays. These bottlenecks can be attributed to litigation within the insolvency process, and especially appeals, and also to difficulties in the collection and sale of assets.

Insolvency cases tend to be initiated too late, limiting the possibilities of recovery. Various incentives have been introduced for debtor companies to initiate debt restructuring at an earlier point in time, such as the possibility that management remains in control during reorganization (concordato preventivo). However, disincentives that would push directors to seek adequate restructuring solutions do not seem to be working effectively.

The Italian authorities have as a matter of priority introduced changes to their insolvency and enforcement framework. A series of measures designed to tackle the NPL problem was included in the Decree-law of June 27, 2015, converted by Parliament into a Law on August 6, 2015.22 The Decree-Law and the Law included numerous measures, most of which relate to insolvency law and civil procedure. ${ }^{23}$ Insolvency reforms incorporate changes to the regulation of interim finance, the introduction of competing reorganization plans and competing bids in the sale of businesses, strict deadlines for liquidations, and a new modality of debt restructuring agreement for financial claims. Other reforms have sought to reduce the length of enforcement procedures, improving the criteria for accepting bids, facilitating payment in auctions and the assignment of property to creditors. The use of information technology for the

\footnotetext{
${ }^{22}$ See Decree-Law of June 27, 2015 (n. 83) and Law of August 6, 2015 (n. 132).

${ }^{23}$ For an analysis of the positive impact of the reforms, see Marcucci, Pischedda, and Profeta (2015).
} 
search of assets belonging to the debtor and the introduction of an electronic portal for sales also represent significant developments. ${ }^{24}$

The latest reform has focused on the improvement of the enforcement of secured credit. The decree-law of May 5, 2016 has introduced out-of-court enforcement for secured credit in commercial credit relationships. This mechanism affects immovable collateral and is based on the technique of the conditional transmission of ownership ("patto marziano"). This is, undoubtedly, an extremely significant reform in creditor rights, which can signal a turning point, especially for the flow of NPLs. In addition, the decree-law has reformed the law on secured transactions for enterprise assets, although several implementation actions will be required to make the new system operational.

The reforms have improved the quality of the legal framework, but there are important challenges in the institutional framework. The general problems affecting the civil justice system are especially relevant in the area of insolvency and creditor rights. The judiciary is overburdened and lacks specialization in debt enforcement, restructuring and insolvency. The enterprise courts (tribunali delle imprese, created in 2012) do not have competences on insolvency matters. Instead, insolvency cases are adjudicated by the sections of the civil courts, preventing specialization in the smaller districts. In addition, there are no specific qualifications for insolvency administrators, and their professionalization is limited. The expertise of administrators is focused on liquidation rather than in the reorganization of enterprises.

\section{OPTIONS FOR BRINGING DOWN NPLS}

The size and prevalence of NPLs call for a comprehensive and rapidly deployed strategy. This section first presents some further preliminary recommendations to reduce the stock and decelerate the flow of NPLs. In a nutshell, this may involve a "stick-and-carrot" approach, with banks facing strong disincentives/incentives for keeping/removing NPLs from their balance sheets. The second part of the section will look at further legal recommendations to improve systematically the conditions for corporate debt enforcement, debt restructuring, and insolvency.

\section{A. Recommendations for Reducing NPLs}

Below are a number of further elements of a comprehensive strategy that could usefully be considered to ensure NPLs are resolved decisively over the medium term.

- Resolving any remaining uncertainty about Italian banks' asset quality and capital buffers. Applying a common asset classification system, the ECB's 2014 Comprehensive

\footnotetext{
${ }^{24}$ See Art. 532 of the code of civil procedure (for sales through private agents), and Arts. 432 -bis, and 490 of the civil procedure code, for the electronic portal for sales. Art. 161-ter of the civil procedure code also foresees electronic sales of assets.
} 
Assessment revealed sizeable provisioning gaps among the 15 participating banks (which were filled during 2015). However, uncertainty remains, at least concerning the rest of the Italian banking system, despite a notable increase in provisioning ratios. Since January 2015, a new asset classification framework harmonized on the EU level (which is in line with earlier supervisory policy on provisioning) has become effective and is applicable to all banks operating in Italy. While applying this standard should be complemented with on-site inspections to ensure smaller banks are accurately classifying and valuing loan assets, importantly, subjecting banks that are not under the supervision of the Single Supervisory Mechanism (SSM) to a process of capital assessment following an asset quality review would clarify uncertainty, with follow-up actions in line with regulatory requirements.

- Banks' ability to deal with NPLs. Banks should be required to maintain comprehensive NPL strategies with ambitious targets to reduce NPLs over the medium term, including a separation of NPLs from 'business as usual' credit management, requiring one member of the executive committee and board of directors to be responsible for the banks' NPL strategy, and development of a comprehensive suite of loan restructuring tools (e.g., as in Greece and Ireland). Consideration should also be given to more comprehensive NPL reporting frameworks ${ }^{25}$ that require banks with high NPL levels to report on a frequent basis; a code of conduct to specify the terms of debtor engagement (e.g., as in Cyprus, Greece, Ireland, and Spain); guidance on banks' approaches to loan provisioning (e.g., as in Cyprus and Ireland); require that loans owned/managed by nonbanks are subject to the same borrower protection through introducing a licensing/regulation regime for nonbanks (e.g., as in Greece and Ireland); and develop debt restructuring principles for multilateral workouts (e.g., as in Austria and Slovenia).

- Strengthened supervision. As NPL management is highly specialized, dedicated expert teams of supervisors could critically review banks' NPL strategies, provide comprehensive feedback on their implementation, and require urgent mitigation in areas where shortfalls are identified. Supervision should strictly enforce banks' compliance with existing and future rules and guidance, including the issuance of further guidance on and regulation of NPL management in banks. ${ }^{26}$ Forthcoming IFRS 9 will include a clear definition of write-off. ${ }^{27}$ When the new accounting rules become applicable, scheduled for 2018, banks need to write off earlier, opening the way for corporate restructuring or liquidation. Common definitions

\footnotetext{
${ }^{25}$ In addition to the Italian credit register, as mentioned above, the BoI plans to collect data on NPL portfolios from all Italian banks. This is expected to be completed by mid-2016.

${ }^{26}$ The BoI's earlier guidance on writing off defaulted exposures would need to be enforced strictly. As mentioned, IAS 39 does not define when and how uncollectable loans are to be written off. Therefore, until the new international accounting rules become effective, it is critical that banks adhere to BoI guidelines.

${ }^{27}$ Loan de-recognition requires the exhaustion of all legal means or to waive contractual rights on the loan before the exposure can be removed from the balance sheet. IFRS 9 will include a definition of write-off different from loan cancellation.
} 
can help improve cross-country comparability, increase transparency, and reduce forbearance going forward.

- Strong incentives for removing in a timely manner bad debt from balance sheets. Consideration could be given to time-bound tax incentives to encourage accelerated workouts and remove bad debt and real estate assets from balance sheets. Supervision and, more specifically, asset classification, should ensure that the potential for ever-greening and misreporting is minimized.

- Further development of the Italian market for restructuring NPLs. Involving outside investors that work together with the banks on corporate restructuring, or directly purchase NPLs, can be seen as a regular tool in the management of NPLs. The transfer of NPLs would relieve banks from the burden of debt collection and foreclosure, and quicker resolution can help conserve recovery values, facilitate debt restructuring and debt/equity conversions, inject capital into firms, and clean-up Italy's corporate sector. ${ }^{28}$

- Intra-segmental cooperation to help smaller banks improve their NPL management infrastructure. As discussed in Section III, smaller banks appear to have insufficient risk and NPL management capacity and limited (or no access) to distressed debt markets. ${ }^{29}$ To reduce the stock of NPLs, banks in the same segment of the banking system (e.g., banche popolari) could cooperate in cleaning up balance sheets. One possibility is to establish a corporate restructuring vehicle (CRV) within a bank segment, aimed at managing NPLs and orderly corporate restructuring. Such a vehicle could be owned by the banks but managed independently, in order to facilitate the design of appropriate incentive schemes, as well as the build-up of NPL management capacity within the segment.

- Asset Management Companies (AMCs) can in principle play a useful role in developing a distressed debt market, in particular in the case of a system-wide NPL problem. Centralized, state-backed AMCs can help kick-start a distressed debt market, ${ }^{30}$ and be a useful complement, not a substitute, to the economic incentives, supervisory disincentives, and legal changes outlined above. Decisive NPL resolution can be achieved through setting uniform market standards for pricing distressed assets, conducting regular auctions to facilitate price discovery, and publishing data that facilitates the price discovery, including, for instance, payment history, default rates, and collateral values. However, the authorities appear to have put to rest for now any discussion of AMCs, given not only EU state aid

\footnotetext{
${ }^{28}$ See also Jassaud and Kang (2015); IMF Global Financial Stability Report April 2015.

29 The 2013 FSAP demonstrated that medium-sized banks are less profitable, more vulnerable to macrofinancial shocks, experience relatively more phase-out of capital due to the implementation of Basel III, and were not able to strengthen capital like other banks did (in particular due to their ownership structure).

${ }^{30}$ The European Union State Aid rules (which place constraints on the use of public funds in bank restructurings) and the BRRD are important checks on market distortions and moral hazard.
} 
concerns but also that uncertainty related to any possible AMC was impacting on banks' plans to progress with NPL resolution.

\section{B. Recommendations for Legal Reform}

The recent revisions to the insolvency and enforcement framework represent positive changes and should over time create better conditions for the efficient resolution of NPLs. A systematic revision of recent reforms and additional efforts to strengthen the institutional framework of the insolvency and enforcement system are crucial. The improvements in the legal environment more generally would have positive effects on all methods to resolve nonperforming loans, including through their sale and securitization.

There are a number of legal issues that need to be addressed. The establishment of a special Commission with a mandate to revise the insolvency framework as a whole (Commissione Rordorf, January 2015) ${ }^{31}$ has represented a good opportunity to rationalize the system and address the broad legal issues that complicate the resolution of NPLs in Italy through the insolvency system (see Garrido, 2016). The Commission presented its report and legislative proposals on January 2016. ${ }^{32}$ The Italian Government decided to submit to Parliament a proposal of a legislative delegation along the lines suggested by the Commission (February 10, 2016). There is a great degree of convergence between the analysis and proposals of the Commission and IMF recommendations.

- A rationalization and better integration of the different options available to enterprises in distress (informal, hybrid and formal insolvency procedures) would ensure that all these procedures work efficiently and seamlessly. Debt restructuring mechanisms work more effectively in a continuum with formal insolvency procedures (Garrido, 2012).

- Insolvency procedures should be initiated at an earlier stage, increasing the recovery possibilities, by establishing adequate incentives and disincentives for debtors. The Rordorf Commission is aware of the importance of this "timing problem" in Italy and has recommended an approach based on an "alert procedure", fashioned after a similar procedure in the French system. This is an interesting approach that has not been followed in other countries, probably owing to the interventionist undertones of the procedure. ${ }^{33}$

\footnotetext{
${ }^{31}$ The Commission was established by the Minister of Justice in January 28, 2015 and has a broad mandate of modernization of the Italian insolvency system.

${ }^{32}$ See the report of the Rordorf Commission and its legislative proposals (in Italian) at http://www.dirittobancario.it/news/fallimento-e-procedure-concorsuali/la-proposta-definitiva-della-commissionerordorf-la-riforma-delle-procedure-concorsuali.

${ }^{33}$ The "procédure d'alerte" can be invoked by diverse actors, including the auditors, the shareholders, or the workers' representatives, to require explanations and an action plan from the company's managers, when faced with extraordinary difficulties. This procedure can result in further actions, such as mediation to resolve the debt problems of the company. It is unclear how an alert procedure would be configured in Italian law.
} 
Generally, the preferred approach to resolve the "timing problem" is to establish proper incentives and disincentives for the debtor and its creditors.

- The insolvency regime should also offer wider restructuring possibilities, including recapitalizations and debt/equity swaps without allowing shareholders to interfere with these solutions. The changes introduced by the Decree-Law of June 27, 2015 and the Law of August, 6, 2015 should be accompanied by a wider reflection of the role of individual shareholders, the shareholders' meeting and the debtor's directors in insolvency procedures.

- Creditor priorities may need to be revisited to increase the rate of return for unsecured creditors. A rationalization of creditor priorities in Italian law is long overdue. The proliferation of creditor priorities has resulted, over time, in an increasingly complex ranking of creditors, leaving little space for the satisfaction of unsecured creditors. Public creditors, in particular, have expanded their priority positions in recent reforms, whereas a revision of the ranking of claims would require public creditors, at least, to take a more constructive role in enterprise restructuring, possibly assisted by guidelines on public sector participation in insolvency processes. The Rordorf Commission has identified the revision of creditor priorities as an area in clear need of reform.

- Insolvency processes should be further streamlined, reducing appeals and opportunities for delay, while, at the same time, providing for adequate protection for all participants. This requires a careful consideration of the details of the procedures, and also the specialization of the judiciary and the reinforcement of court officials and insolvency administrators. Recent reforms have established firm deadlines, with consequences in case of noncompliance for the insolvency administrator. It remains to be seen whether this results in an acceleration of the insolvency process.

- The increased flexibility in the sale of assets should be effectively implemented. The Ministry of Justice has projected a national platform for insolvency and enforcement sales, with the possibility of delivering certificates to creditors corresponding to the projected value of their claims (Project "Common"). Creditors would be able to trade the certificates or to use them to bid for other assets for sale, instead of waiting for the conclusion of the liquidation to obtain satisfaction of their claims. This is an innovative project that deserves serious study and consideration.

- A broader reform could also include a simplified debt restructuring mechanism for SMEs, preferably a hybrid framework (Bergthaler and others, 2015), based on a triage approach establishing the viability of SMEs according to basic objective indicators. A specific set of debt restructuring principles could address the situation of over-indebted SMEs, introducing clear guidance and criteria for debt restructuring decisions.

- Further reforms to increase the efficiency of individual enforcement procedures would reinforce the positive effects of insolvency reforms. Continuous reform of court procedures, the introduction of electronic processes and the extension of best practices in court 
management to courts across the whole country represent important measures for the general improvement of the system.

- The legal environment of credit can greatly benefit from reforms of the law of secured transactions. Changes in this area will improve the possibility of creating security interests over movable assets, with corresponding reforms of the registration systems (Box 4). The recent reform of secured transactions still requires work on numerous technical questions that need to be addressed for the implementation of an effective secured transactions system.

- The institutional framework for insolvency and creditor rights remains a substantial challenge. The program of judicial reforms, especially focused on civil justice, should continue. Further special measures to address the backlog at the courts seem necessary. These could include further specialization of judges in commercial matters, especially in debt enforcement, restructuring and insolvency. While in smaller districts, the de facto specialization of judges would not be possible, courts in larger towns would benefit from having civil judges specialize in insolvency matters. The proposals of the Rordorf Commission are aligned with the goal of increasing the specialization of the courts in insolvency matters. Strengthening the enterprise courts and increasing their competences is the most promising option. In addition, the regime of insolvency administrators should be reinforced to improve the quality of debt restructuring solutions for distressed enterprises.

Legal reforms are more effective in reducing the flow of NPLs than in dealing with the existing stock. The reason is that some of the most important reforms, such as out-of-court enforcement of secured credit, do not affect existing credit relationships. For the current NPL stock, legal reforms should be combined with a more intensive use of informal debt restructuring. Workout practice would benefit from the adoption of debt restructuring principles by the financial sector (in line with the "London Approach," or the INSOL Principles). 


\section{Box 4. The Importance of Efficient Secured Transaction Laws}

Security rights provide certainty for creditors and increase access to finance. The importance of the secured transactions system has been highlighted by legal and economic experts, and has given rise to detailed best practice recommendations (UNCITRAL, 2007). The possibility of using different types of collateral creates opportunities for more efficient financing arrangements. This is the case with the creation of security interests over movable collateral: there are important differences in the flexibility and efficiency of secured transactions over movable assets. These affect the availability of credit for enterprises, particularly SMEs.

The use of movable collateral in the context of entrepreneurial activities requires a high degree of flexibility in the creation of security interests. These should cover not only specific assets, such as machinery, but also categories of assets, such as inventory, equipment and accounts receivable, without the need to specify each and every asset covered by the security interest. The main reason is that these security interests should allow the debtor to remain in possession of the assets. This implies that the debtor will be able to use the assets, and even, with respect to inventory, to sell the assets in the ordinary course of business. Dispossession of the debtor is not necessary because these security interests are recorded in public registries. Registries are "notice based": they merely provide notice to the public of the creation of the security interest. Registries are computerized and allow for interaction with other registries and databases.

Priority of the security interest is another crucial element in the design of the legal framework. The protection of the borrowers' interests, and the corresponding positive effects for borrowers, require that the position of the secured creditor be granted a priority status. Registration establishes the point in time when the lender acquires his priority rights versus other creditors and third parties.

Finally, an efficient secured transactions system requires swift enforcement of the secured claim. In the case of movable collateral, the speed in enforcement of the secured claim is critical because the depreciation of assets is fast. Enforcement mechanisms may include summary judicial procedures or out-of-court enforcement. The possibility of using fiduciary contracts can be understood in this context as one way of improving the enforcement of security interests over movable collateral without having to resort to the court system.

The economic importance of efficient secured transactions laws has been emphasized in the economic literature. According to recent research, loan-to-values of loans collateralized with movable assets are on average 21 percentage points higher in countries with strong collateral laws relative to immovable assets. Further, stronger collateral laws tilt collateral composition away from immovable to movable assets (Calomiris and others, 2015). In terms of their effect on NPLs, secured transactions reforms do not reduce the stock of NPLs, but can reduce significantly the flow of new NPLs in the banking system.

\section{Conclusions}

NPLs in Italy have reached high levels, hindering the recovery. Cleaning up banks' balance sheets is crucial to encourage credit growth, especially to SMEs that are more reliant on bank financing. Resolving impaired loans would also help facilitate restructuring or resolution of distressed SMEs.

The purpose of this paper is two-fold: diagnose the nature and extent of the NPL problem in Italy, and provide a comprehensive strategy for NPL resolution. Our main findings are as follows:

- The NPL problem in Italy has several specific features that need to be taken into account when devising a potential solution, including a pronounced regional dimension and 
concentration of NPLs in the corporate sector. Large banks hold the lion's share of NPLs, but NPL ratios are high across all types of banks suggesting a system-wide problem.

- Dynamic bank-by-bank panel regressions suggest that lower profitability and faster loan book expansion on average have resulted in worse asset quality. A number of macroeconomic conditions including lower growth, exchange rate appreciations, and falling house prices are also significantly associated with higher NPLs.

- The prolonged recession led to higher default risks in corporates and banks. A dynamic macrofinancial State Space model illustrates how the dynamics have changed over the past few years. The estimates suggest that (1) further output losses would fuel credit risk considerably more than in the past; and (2) higher interest rates would now have a much more substantial impact on corporates than in the past.

- The size and prevalence of NPLs call for a comprehensive strategy including economic, supervisory, and legal measures. The Italian authorities have implemented a number of reforms in recent years aimed at speeding up bankruptcy and foreclosure proceedings, fostering bank provisioning, easing NPLs' disposal and strengthening bank corporate governance. This paper argues that further actions, in the supervisory, legal, and economic areas, are needed to support these measures. 


\section{References}

Aiyar, S., Bergthaler, W., Garrido, J., Ilyina, A., Jobst, A., Kang, K., Kovtun, D., Liu, Y., Monaghan, D., and Moretti, M., (2015), "A Strategy for Resolving Europe's Bad Loans,” IMF Staff Discussion Note 15/19 (Washington: International Monetary Fund).

Auricchio, A., and Gismondi, R., 2015, “The Italian Expedited Restructuring Remedies and Proceedings," in Expedited Corporate Restructuring in the EU, ed. by R. OlivaresCaminal (United Kingdom: Oxford University Press).

Bank of Italy, 2015, Financial Stability Report, No. 1 (April).

Bergthaler, W., Kang, K., Liu, Y., and Monaghan, D., 2015, “Tackling Small and MediumSized Enterprise Problem Loans in Europe," IMF Staff Discussion Note 15/04 (Washington: International Monetary Fund).

Bisogno, M., 2012, “The Accessibility of the Italian Bankruptcy Procedures: An Empirical Analysis," Eurasian Business Review, Vol.2, No. 2, pp. 1-24.

Bisogno, M., and De Luca, R., 2014, "Bankruptcy Efficiency and Indirect Costs in Italian SMEs: a Temporal Approach," International Journal of Business Research and Development, Vol. 3, No. 2.

Calomiris, C.W., Larrain, M., Liberti, J., and Sturgess, J., 2015, "How Collateral Laws Shape Lending and Sectoral Activity," Columbia Business School Research Paper No. 14-58.

Carpinelli, L., Cascarino, G., Giacomelli, S., and Vacca, V., 2016, The Management of Nonperforming Loans: a Survey Among the Main Italian Banks, Occasional Paper No. 311 (Banca d'Italia).

Castelli, C., Micucci, G., Rodano, G., and Romano, G., 2016, "Il concordato preventivo in Italia: una valutazione delle riforme e del suo utilizzo," Questioni di Economia e Finanza, No. 316 (Banca d'Italia).

Cerved, 2015, Osservatorio su Fallimenti, Procedure e Chiusure di Imprese (4th Quarter 2014).

Ciavoliello L. G. , Ciocchetta F., Conti, F.M., Guida I., Rendina, A., and G. Santini, 2016, "What is the Value of NPLs?" Notes on Financial Stability and Supervision, No. 3 (April).

Deutsche Bank, 2016, "State Guarantee on NPL Securitization: Not Enough, But it Helps," Deutsche Bank Markets Research, http://pull.db-gmresearch.com/cgibin/pull/DocPull/1283-140F/80692009/0900b8c08ab78c12.pdf. 
Garrido, J. M., 2016, “Insolvency and Enforcement Reforms in Italy,” IMF working paper, forthcoming (Washington: International Monetary Fund).

Garrido, J. M., 2012, Out-of-Court Debt Restructuring (Washington: World Bank).

Gennaioli, N., and Rossi, S., 2010 “Judicial Discretion in Corporate Bankruptcy," Review of Financial Studies, Vol. 23, No. 11, p. 4078.

International Monetary Fund, 2013, "Italy: Financial System Stability Assessment," IMF Country Report 13/300 (Washington).

— , 2015, “Italy: Article IV Consultation,” IMF Country Report 15/166 (Washington).

—_ 2015, “Italy: Selected Issues,” IMF Country Report 15/167 (Washington).

Jappelli, T., Pagano, M., and Bianco, M., 2005, "Courts and Banks: Effects of Judicial Enforcement on Credit Markets," Journal of Money, Credit and Banking, Vol. 37, No. 2, p. 223.

Jassaud, N., 2014, "Reforming the Corporate Governance of Italian Banks," IMF WP/14/181 (Washington: International Monetary Fund).

Jassaud, N., and Kang, K., 2015, “A Strategy for Developing a Market for Nonperforming Loans in Italy," IMF WP/15/24 (Washington: International Monetary Fund).

Jobst, A., and Weber, A., 2016, "Profitability and Balance Sheet Repair of Italian Banks," in Italy: Selected Issues (Washington: International Monetary Fund).

JP Morgan, 2016, "Mind The Gap: Estimating the transfer price and participation in the Italian SPVs (bad bank), JP Morgan Europe Credit Research (February 1).

Klein, N., 2013, "Nonperforming Loans in CESEE: Determinants and Impact on Macroeconomic Performance," IMF WP/13/72 (Washington: International Monetary Fund).

Lanau, S., Esposito, G., and Pompe, S. 2014, "Judicial System Reform in Italy-A Key to Growth,” IMF WP/14/32 (Washington: International Monetary Fund).

Marcucci, M., Pischedda, A., and Profeta, V. 2015, "The Changes of the Italian Insolvency and Foreclosure Regulation Adopted in 2015,"Notes on Financial Stability and Supervision, No. 2 (Banca d'Italia).

Panzani, L.,2009, “The Italian Bankruptcy Law Reform- Act III,” Norton Annual Review of International Insolvency, 301. 
Rath, C., 2014, "Effects of Collateral Law Reform on Firms' Access to Finance," Essays on the Political Economy of Institutions, Theses and Dissertations, UWM Paper 483.

Rodano, G., Serrano-Velarde, N., and Tarantino, E., 2015, "Bankruptcy Law and Bank Financing” Innocenzo Gasparini Institute for Economic Research, Working Paper No. 547.

Rordorf Commission: Report and Legislative Proposals, http://www.dirittobancario.it/news/fallimento-e-procedure-concorsuali/la-propostadefinitiva-della-commissione-rordorf-la-riforma-delle-procedure-concorsuali.

Savafian, M., Fleisig, H., and Steinbuks, J., 2006, "Unblocking Dead Capital: How Reforming Collateral Laws Improves Access to Finance," Private Sector Development Viewpoint, No. 307 (Washington: World Bank).

UNCITRAL, 2007, Legislative Guide on Secured Transactions (New York: United Nations, published 2010).

World Bank, 2003, Analyzing and Managing Banking Risk, A Framework for Assessing Corporate Governance and Financial Risk (Washington, $2^{\text {nd }}$ ed.). 


\section{Annex. Dynamic Bank-by-Bank Panel Regressions}

\section{Smaller Sample (SNL Full Coverage)}

Fixed Effects Panel Regression 2005-2014

\begin{tabular}{l|ll}
\hline NPL & Coefficient & P-value \\
\hline NPLs (-1) & 0.89 & 0.00 \\
Inflation (-1) & 0.02 & 0.66 \\
REER 1/ & 0.14 & 0.00 \\
Real GDP Growth (-1) & -0.26 & 0.00 \\
Stock Price Growth & 0.01 & 0.15 \\
House Price Growth & -0.19 & 0.00 \\
Equity-to-Assets (-1) & 0.01 & 0.87 \\
RoE (-1) & -0.07 & 0.00 \\
Loan growth (-1) & 0.001 & 0.11 \\
Tier 1 (-1) & -0.04 & 0.24 \\
Constant & 2.78 & 0.00 \\
2008 Dummy & -0.45 & 0.20 \\
2011 Dummy & -0.64 & 0.06 \\
\hline R-squared(within) & 0.87 & \\
R-squared (between) & 0.95 & \\
No. of banks & 57 & \\
No. of observations & 309 & \\
\hline Sources: SNL, World Economic Outlook. & & \\
1/ An increase in RERR indicates apprecition & & \\
& &
\end{tabular}

1/ An increase in REER indicates appreciation.

System GMM Estimation, 2005-2014 (Two-Step Robust Estimates)

\begin{tabular}{l|ll}
\hline $\boldsymbol{N P L}$ & Coefficient & $\boldsymbol{P}$-value \\
\hline NPLs (-1) & 1.16 & 0.00 \\
Inflation (-1) & -0.05 & 0.06 \\
REER 1/ & 0.12 & 0.01 \\
Real GDP Growth (-1) & -0.24 & 0.00 \\
Stock Price Growth & -0.01 & 0.33 \\
House Price Growth & 0.002 & 0.98 \\
& & \\
Equity-to-Assets (-1) & 0.11 & 0.28 \\
RoE (-1) & -0.04 & 0.02 \\
Loan growth (-1) & 0.001 & 0.04 \\
Tier 1 (-1) & -0.06 & 0.30 \\
Constant & 0.08 & 0.96 \\
Dummy 2008 & -0.36 & 0.48 \\
Dummy 2011 & -0.02 & 0.94 \\
Arellano-Bond AR (1) p-value & 0.02 & \\
Arellano-Bond AR (2) p-value & 0.24 & \\
Hansen test p-value & 0.86 & \\
No. of banks & 57 &
\end{tabular}


System GMM Estimation, 2005-2014 (Two-Step Robust Estimates) (continued)

No. of observations 309

No. of instruments 28

Sources: SNL, World Economic Outlook.

1/ An increase in REER indicates appreciation.

\section{Larger Sample (SNL Summary Coverage)}

Fixed Effects Panel Regression 2005-2014

\begin{tabular}{l|ll}
\hline NPL & Coefficient & P-value \\
\hline NPLs (-1) & 0.62 & 0.00 \\
Inflation (-1) & 0.09 & 0.42 \\
REER 1/ & 0.17 & 0.00 \\
Real GDP Growth (-1) & -0.34 & 0.00 \\
Stock Price Growth & 0.04 & 0.06 \\
House Price Growth & -0.42 & 0.00 \\
RoE (-1) & -0.05 & 0.00 \\
Loan growth (-1) & 0.001 & 0.14 \\
Tier 1 (-1) & 0.00 & 0.995 \\
Constant & 5.4 & 0.00 \\
2008 Dummy & -0.68 & 0.15 \\
2011 Dummy & -1.06 & 0.01 \\
R-squared(within) & 0.72 & \\
R-squared (between) & 0.93 & \\
No. of banks & 326 & \\
No. of observations & 805 & \\
\hline So & & \\
\hline
\end{tabular}

Sources: SNL, World Economic Outlook.

1/ An increase in REER indicates appreciation. 